\title{
Potential of Sambiloto (Andrographis paniculata Nees) Extract against Salmonella Pullorum
}

Sri Hidanah ${ }^{1}$, Emy Koestanti Sabdoningrum ${ }^{1,2}$, Soeharsono $^{3}$, Ayu Andira ${ }^{4}$, Noor Amina Varhana ${ }^{4}$

10.18805/IJAR.BF-1445

\begin{abstract}
Background: Salmonella Pullorum are pathogenic bacteria that causes salmonellosis and causes heavy economic losses in the poultry industry and are zoonotic. Treatment of diseases caused by bacteria generally use antibiotics, but excessive administration of antibiotics causes bacterial resistance and residues in livestock. Major chemical constituents of Sambiloto are andrographolide and flavonoids. Andrographolide has antibacterial effect in addition to being antitoxic, anticancer, anti-inflammatory and antiallergic.

Methods: The research was conducted by isolating and identifying Salmonella Pullorum on SSA media and a series of biochemical tests (TSIA, SIM, SCA, urea media and sugar test), manufacturing sambiloto extract, testing the sensitivity of several antibiotics using the disk diffusion method and testing the activation of sambiloto extract against Salmonella Pullorum using the disk diffusion and dilution methods.

Result: The result show that sambiloto had antibacterial activity because it contained andrographolide, flavonoids, saponins, alkaloids and tannins and the lowest extract dose that effectively killed Salmonella Pullorum is concentrations of $20 \%$.

Key words: Andrographis paniculata. Antibacteria, Salmonella pullorum.
\end{abstract}

\section{INTRODUCTION}

Salmonella Pullorum is a pathogenic agent that causes salmonellosis in chickens. Salmonellosis is an infectious disease and causes high morbidity and mortality in chickens, causing heavy economic losses in the poultry industry and zoonotic (Sabdoningrum et al., 2020). Transmission of salmonellosis can be direct and indirect contact. Indirectly, humans are infected when consuming undercoocked livestock products, especially eggs suspected of being infected with Salmonella Pullorum (Chlebiez and Sliżewska, 2018).

Treatment of diseases caused by bacteria generally use antibiotics. Excessive administration of antibiotics causes bacterial resistance and residues in livestock products which will affect public health. The types of antibiotics that are often used to treat salmonellosis are enrofloxacin, tylosin and tetracycline (Sànchez-Salazar et al., 2019; Savin et al, 2021). All these antibiotics are commonly used to treat poultry salmonellosis in Indonesia. Bacterial resistance to antibiotics makes the disease difficult to treat because high doses have to be used which increases the cost of treatment. The use of herbal medicine is an alternative to replace antibiotics (Wahyuni et al., 2017). A large number of plants and their isolated constituents have shown beneficial therapeutic effects (Miller et al., 2004; Narayanan et al., 2021; Ansori et al., 2021). Giving plant ingredients to chickens has been proven to provide a positive response for growth and immunity (Akhsan et al., 2020; Sabdoningrum et al., 2020). One of the uses of herbal medicine is sambiloto (Andrographis paniculata Nees). The major chemical contituents of sambiloto are andrographolide and flavonoids. Andrographolide has an antibacterial effect
1Division of Animal Husbandry, Faculty of Veterinary Medicine, Universitas Airlangga, Surabaya, Indonesia.

${ }^{2}$ Veterinary Science Doctoral Program, Faculty of Veterinary Medicine, Universitas Airlangga, Surabaya, Indonesia.

${ }^{3}$ Division of Veterinary Anatomy, Faculty of Veterinary Medicine, Universitas Airlangga, Surabaya, Indonesia.

${ }^{4}$ Undergraduate Program, Faculty of Veterinary Medicine, Universitas Airlangga, Surabaya, Indonesia.

Corresponding Author: Emy Koestanti Sabdoningrum, Division of Animal Husbandry, Faculty of Veterinary Medicine, Universitas Airlangga, Surabaya, Indonesia. Email: emykoestanti10@gmail.com

How to cite this article: Hidanah, S., Sabdoningrum, E.K., Soeharsono, Andira, A. and Varhana, N.A. (2022). Potential of Sambiloto (Andrographis paniculata Nees) Extract against Salmonella Pullorum. Indian Journal of Animal Research. DOI: $10.18805 /$ IJAR.BF-1445.

Submitted: 30-09-2021 Accepted: 13-12-2021 Online: 16-01-2022

in addition to being antitoxic, anticancer, anti-inflammatory and antiallergic. Sambiloto also contains xanthones, neoandrogtapholide and diterpene phytoconstituents as antidiarrheal and 14-deoxyandrographolide and 14-deoxy11,12 dehydroandrographolide compounds as antioxidants. In addition, sambiloto also contains saponins, alkaloids and tannins (Nasution et al., 2019; Suwarta et al., 2021).

Based on the description above, a study was conducted on the phytogenic potential of the feed additive of sambiloto extract (Andrographis paniculata Nees) on the economic value of feed and income over feed cost in laying eggs with salmonellosis. 


\section{MATERIALS AND METHODS} Isolation and identification of Salmonella pullorum

Based on the bacterial detection test that was carried out by Fatiqin et al. (2019), the isolation and identification of Salmonella Pullorum began with the manufacture of $35 \mathrm{~g}$ of SSA media dissolved in 1 liter of distilled water, then boiled and sterilized using an autoclave for 30 minutes at temperature of $121^{\circ} \mathrm{C}, 1 \mathrm{~atm}$. A total of $10 \mathrm{~g}$ sample (which has been mashed) placed on aluminum foil, then mixed into $90 \mathrm{ml}$ of sterile distilled water $\left(10^{-1}\right.$ dilution). Shook by using cortex until the sample dissolved homogeneously. A total of $1 \mathrm{ml}$ of the solution at a dilution of $10^{-1}$ was taken and put into a test tube containing $9 \mathrm{ml}$ of new sterile distilled water (dilution $10^{-2}$ ). A total of $1 \mathrm{ml}$ of the sample suspension solution at dilutions of $10^{-1}$ and $10^{-2}$ was taken by pour plate method on Salmonella-Shigella Agar (SSA) media. Then incubated at $37^{\circ} \mathrm{C}$ for 24 hours.

The Salmonella Pullorum culture was then cultured in liquid medium by inserting 4-10 oses of Salmonella Pullorum which had previously been planted in agar media into an Erlenmeyer containing $25 \mathrm{ml}$ of PBS solution. The turbidity of the bacterial suspension was equalized with Mc Farland tube No. $1\left(3 \times 10^{8} \mathrm{cells} / \mathrm{ml}\right)$, then diluted by adding $50 \mathrm{ml}$ of PBS solution to obtain $1 \times 10^{8}$ cells $/ \mathrm{ml}$. The identification the continued by biochemical tests.

\section{Biochemical test}

The biochemical test carried out was on triple sugar Iron agar (TSIA), sulfide indol motility (SIM), simmon citrate agar (SCA), urea agar and sugar test which consisted of glucose, mannitol, maltose, sucrose and lactose.

\section{Extraction of Sambiloto (Andrographis paniculata Nees)}

The simplicia powder was extracted by ethanol maceration method for approximately three days. The ratio of samobilo powder with ethanol solvent was 1:3 (Laksmiani et al, 2015). The maceration process was accompanied by periodic stirring. The obtained liquid extract from then were filtered through filter paper (Ousaaid et al., 2020). The macerate was evaporated with a rotary evaporator until no solvent was left behind and produced sambiloto extract (Mardiana and Handayani, 2016). Then, sambiloto extract was diluted with distilled water to obtain 4 tubes of sambiloto extract with concentrations of $5 \%, 10 \%, 20 \%$ and $40 \%$. Concentrations were made by dissolving CMC-Na 0.5\% (0.5 grams in $100 \mathrm{ml}$ of $70^{\circ} \mathrm{C}$ warm aquadest) then mixed with sambiloto extract according to the concentration calculation.

\section{Phytochemical screening}

\section{Andrographolide test}

Cold maceration of leaf powder in 1:1 mixture ratio of dichloromethane and methanol were conducted and followed by recrystallization (Novitasari et al., 2020).

\section{Alkaloid test}

Alkaloid test was carried out using Wegner's Reagent. The extracts were treated with $1 \mathrm{~mL}$ Wagner's reagent and then formation of reddish-brown precipitate or colouration was observed (Kokate et al., 2001; Rani et al., 2017).

\section{Flavonoid test}

Sample was evaporated and washed with hexane then the residue was dissolved in $20 \mathrm{~mL}$ of ethanol and filtered. The filtrate was divided into 4 parts (A, B, C and D). Filtrate divided as blank, added $\mathrm{HCl} 0.5 \mathrm{~mL}$ then heated, added with $0.5 \mathrm{~mL}$ of $\mathrm{HCl}$ and $\mathrm{Mg}$ the color changes were then observed.

\section{Saponin test}

Used the forth method and the changes were observed. Formation of solid foam is the indication of saponin.

\section{Tannin test}

Sample was put into boiling flask, distilled water was added and then refluxed for 3 hours. The sample was cooled and transferred into volumetric flask, then filtered. $2 \mathrm{ml}$ of filtrate then added to volumetric flask. Folin Denis reagent and saturated $\mathrm{Na}_{2} \mathrm{CO}_{3}$ were added and then the absorbance was measured. $\mathrm{Na}_{2} \mathrm{WO}_{4}$, phospomolybdic acid and $85 \%$ phosphoric acid were added to distilled water, then the mixture was refluxed, cooled and added to distilled water. Anhydrous $\mathrm{Na}_{2} \mathrm{CO}_{3}$ was added to distilled water at stirred and cooled.

\section{Sensitivity test (Disk diffusion method)}

Sensitivity test of Salmonella Pullorum ATCC 13036 bacteria to antibiotics using the disc diffusion test method, by suspending the Salmonella Pullorum isolate according to Mc Farland standard in physiological $\mathrm{NaCl}$ solution and homogenized Then the suspension was poured on mueller hinton agar (MHA) evenly (Mardiah, 2017). Empty antibiotic discs that had been prepared, each filled with antibiotics Enrofloxacin, Oxytetracycline and Tylosin which the dose and concentration used had been calculated. This selection of antibiotics is based on the antibiotic that commonly used to treat poultry salmonellosis in Indonesia.

The antibiotic disc was dipped into a test tube containing diluted antibiotics, sambiloto extract $5 \%, 10 \%, 20 \%$ and $40 \%$. The selection of dilution is based on research conducted by Hidanah et al. (2020) on Avian Pathogenic Eschericia coli and the addition one higher dose because Salmonella Pullorum is more pathogenic than Avian Pathogenic Eschericia coli. The sambiloto extracts then left to stand for 15 minutes, then removed using tweezers and placed on the surface of the media, the disc was pressed with tweezers with minimum distance of $15 \mathrm{~mm}$ between the discs and the discs that had been affixed on the surface of the media must not be moved or shifted. The MHA medium was then incubated at $37^{\circ} \mathrm{C}$ for $16-18$ hours and the zone of inhibition was measured.

The test results then were interpreted in Table 1 which related to the standard interpretation of the zone diameter and the level of resistance to determine the sensitivity of bacteria to antibiotics, grouped into three categories: 
sensitive (S), intermediate (I) and resistant (R) according to the Clinical and Laboratory Standards Institute standards.

\section{Dilution method}

Included minimum inhibitory concentration (MIC) and Minimum Bactericidal Concentration (MBC) (Owuama, 2017). MIC was done by using preparing -20 test tubes for 5 treatments $\times 4$ replications for each treatment. Sambiloto extract $5 \%, 10 \%, 20 \%$ and $40 \%$ and also antibiotics Enrofloxacin, Oxytetracycline and Tylosin were added $3 \mathrm{ml}$ each into test tube, then for each concentration a Salmonella pullorum $\left(1 \times 10^{8} \mathrm{CFU} / \mathrm{ml}\right)$ bacterial suspension was added as much as $3 \mathrm{ml}$ in each concentration was then incubated at $37^{\circ} \mathrm{C}$ for 24 hours. The results were observed by looking cloudy or clear at each concentration that had been planted with Salmonella Pullorum

Minimum bactericide concentration (MBC) was carried out using 5 plates of nutrient agar (NA) media, i.e. each plate was divided into 5 treatments. The results of the MIC test were planted on NA media by stretching them at the concentration in the media, incubating at $37^{\circ} \mathrm{C}$ for 24 hours. Results could be observed by the presence or absence of growth of Salmonella Pullorum colonies on NA media.

\section{RESULTS AND DISCUSSION}

\section{Isolation and identification of Salmonella Pullorum}

The result of the isolation and identification of Salmonella Pullorum bacteria showed that the bacteria used met with the criteria. The results on Salmonella Shigella Agar (SSA) media appeared transparent in color with round black spots. The picture of bacterial colonies can be seen in Fig 1 .

\section{Biochemical test}

The results of the identification test are triple sugar iron agar (TSIA) which shows the slant part was red-orange and the upright was yellow and positive $\mathrm{H} 2 \mathrm{~S}$ gas production was marked with black in the butt, sulfide indole motility (SIM) test showed non-motile bacteria, indole was negative and $\mathrm{H} 2 \mathrm{~S}$ was positive, then in the positive simon citrate agar (SCA) test it was indicated by a color change in the media from green to blue, then in the negative Urease test it was indicated by no change in the media from yellow to pink and finally the sugar test which consisted of positive glucose, mannitol and maltose was positive, indicated by a change in the color of the media to yellow, while negative sucrose and lactose did not change the color of the media, the media remained red, as could be seen in Fig 2 and 3.

\section{Sensitivity test (Disk diffusion method)}

The result of Salmonella pullorum resistance toward antibiotics by using enrofloxacin, tylosin and oxytetracycline

Table 1: Interpretation standards of the diameter of the inhibition zone.

\begin{tabular}{lccc}
\hline Antibiotic & Sensitive (S) & Intermediate (I) & Resistance (R) \\
\hline Enrofloxacin & $\geq 23 \mathrm{~mm}$ & $17-22 \mathrm{~mm}$ & $\leq 16 \mathrm{~mm}$ \\
Oxytetracycline & $\geq 15 \mathrm{~mm}$ & $12-14 \mathrm{~mm}$ & $\leq 11 \mathrm{~mm}$ \\
Tylosin & $\geq 26 \mathrm{~mm}$ & $23-25 \mathrm{~mm}$ & $\leq 22 \mathrm{~mm}$ \\
\hline
\end{tabular}

was presented in Table 2. The results of the statistical test of the inhibition zone formed from the resistance test of Salmonella pullorum ATCC 13036 to several antibiotics and sambiloto could be seen in Table 3 and Fig 4 . The diameter of the seven preparations analyzed obtained a cut off at a diameter of $12.09 \mathrm{~cm}$. This meant that preparations with a diameter less than this number indicate that there was still bacterial growth. The preparations include sambiloto with a

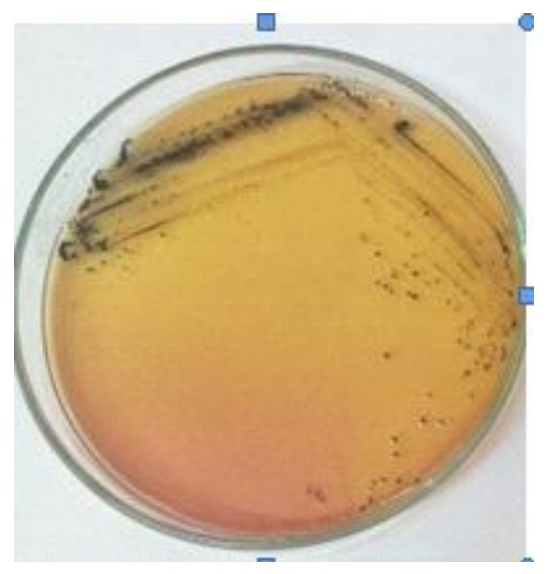

Fig 1: Salmonella-Shigella Agar Media Inoculated with Salmonella pullorum.

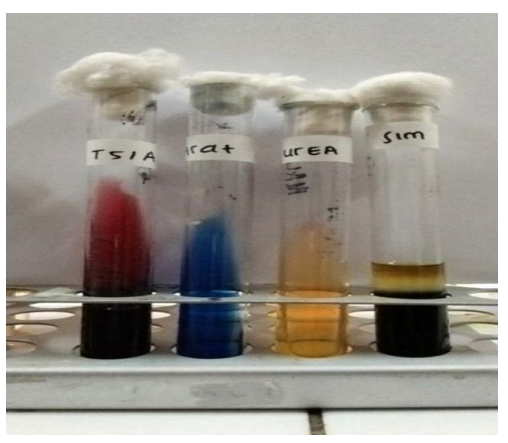

Fig 2: The results of the biochemical test of Salmonella pullorum with TSIA, SCA, urease and SIM.

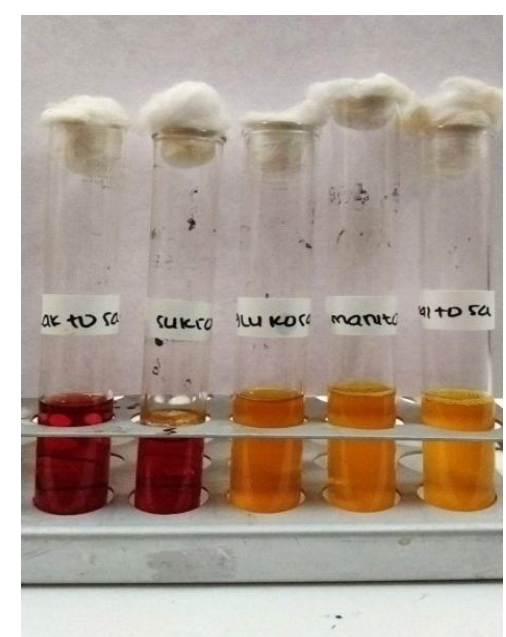

Fig 3: The test results of Salmonella pullorum on sugars test (lactose, sucrose, glucose, mannitol, maltose). 
concentration of $5 \%$ and sambiloto with a concentration of $10 \%$. Analysis of preparations that act as an antibacterial showed that tylosin had the smallest diameter significantly compared to the other six preparations, namely enrofloxacin, oxytetracycline and sambiloto both at concentrations of $20 \%$ and $40 \%(p<0.05)$. The second order after Tylosin was Oxytetracycline $(p<005)$. The diameter of sambiloto at a concentration of $20 \%$ was not significantly different with the same preparation but at a concentration of $40 \%(p>0.05)$. The two preparations were compared with the diameters used as samples in this study, which showed a significantly larger diameter for both Tylosin and Oxytetracycline

Table 2: Resistance test data of Salmonella pullorum ATCC 13036 to enrofloxacin oxytetracycline and tylosin.

\begin{tabular}{lc}
\hline \multicolumn{2}{c}{ Antibiotic inhibition zone grouping } \\
\hline Enrofloxacin & $\mathrm{S}$ \\
Tylosin & $\mathrm{R}$ \\
Oxytetracycline & $\mathrm{S}$
\end{tabular}

Description: (S) Sensitive, (I) Intermediate, (R) Resistant.

Table 3: Average diameter of the inhibition zone of enrofloxacin, tylosin, oxytetracycline and sambiloto.

\begin{tabular}{lc}
\hline Antibiotic & Inhibition zone diameter $(\mathrm{mm})(\mathrm{x} \pm \mathrm{SD})$ \\
\hline Enrofloxacin & $34.22^{\mathrm{e}} \pm 0.62$ \\
Tylosin & $14.25^{\mathrm{c}} \pm 0.70$ \\
Oxytetracycline & $22.99^{\mathrm{d}} \pm 0.84$ \\
Sambiloto $5 \%$ & $7.77^{\mathrm{a}} \pm 0.19$ \\
Sambiloto $10 \%$ & $10.22^{\mathrm{b}} \pm 0.13$ \\
Sambiloto $20 \%$ & $33.62^{\mathrm{e}} \pm 1.36$ \\
Sambiloto $40 \%$ & $33.50^{\mathrm{e}} \pm 0.16$ \\
\hline
\end{tabular}

Note: Different superscripts in the same column show significant differences $(P<0.05)$. $(p<0.05)$, but not significantly different when compared to the diameter of the enrofloxacin treatment $(p>0.05)$.

The results showed that Salmonella pullorum were, sensitive to enrofloxacin and oxytetracycline and also resistant to tylosin. The agar diffusion method (disk diffusion) was a way of testing antibiotic sensitivity by placing antibiotic on media that had been inoculated with Salmonella Pullorum, the antibiotic would diffuse in media that over grown by bacteria. In the diffusion test there was a clear zone on the agar layer, the zone was formed due to the diffusion of antibiotics into the agar layer and inhibited bacterial growth or commonly known as the inhibition zone. Agar layer that was overgrown by bacteria would look cloudy. Antibiotics worked by interacting with the bacterial cell wall and the antibiotic becomes easier to diffuse into the bacterial cell.

Enrofloxacin was a broadspectrum antibiotic that was bactericidal. The mechanism of action of this antibiotic was that when protein synthesis occurs, DNA gyrase will be inhibited. Inhibition of DNA gyrase led to prevention of the positive relaxation of supercoid DNA which was required for normal transcription and replication (Katzung, 2014). Oxytetracycline was a broad spectrum antibiotic with bacteriostatic properties. Oxytetracycline antibiotic worked by inhibiting bacterial protein synthesis on their ribosomes. There were 2 processes for the entry of antibiotic into the ribosomes of gram-negative bacteria. The first way was passive diffusion through hydrophilic channels, while the second way was through an active transport system. After entering, the antibiotic will bind to the $30 \mathrm{~S}$ ribosome and block the tRNA-amino acids so that bacteria could not grow and divide (Miranda and Zemelman, 2002).

The results of this study showed that Salmonella Pullorum were resistant to Tylosin. This was in accordance

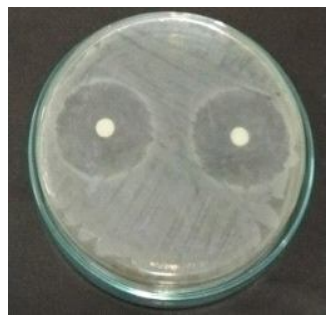

(a)

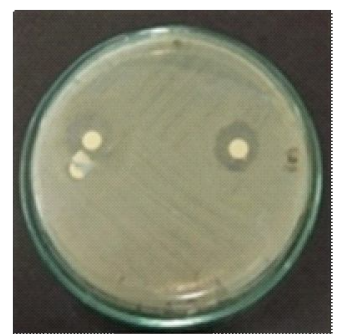

(d)

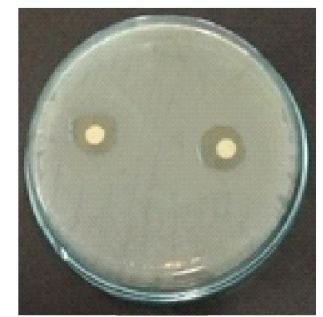

(b)

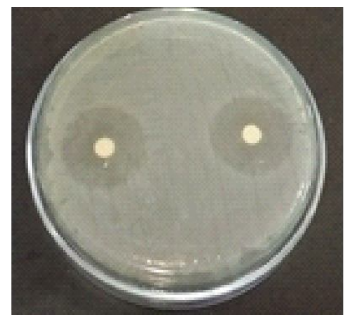

(c)

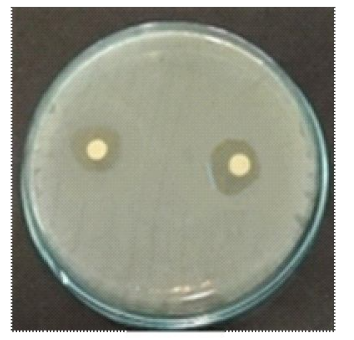

(e)

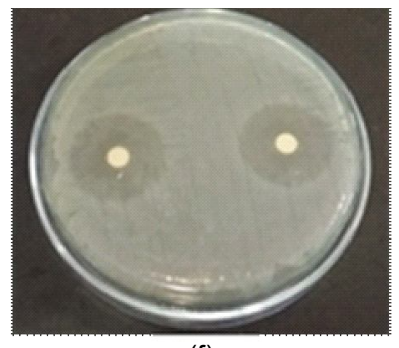

(f)

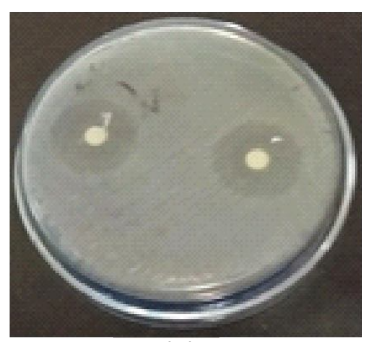

(g)

Fig 4: Zone of Inhibition (a), Enrofloxacin; (b), Oxytetracycline; (c) Tylosin; (d) Sambiloto 5\%; (e) Sambiloto 10\%, (f) Sambiloto $20 \%$, (g) Sambiloto $40 \%$. 
with the statement of Alo and Ojo, (2007) that the Tylosin antibiotic used by farmers as an additive and bacterial treatment has been resistant. This Tylosin antibiotic was fat soluble so it was easy to form a depot in fat tissue. The release of the active form from the depot could result in a prolongation of the effect of the antibiotic, this would result in the effect of bacterial resistance to the Tylosin antibiotic (Wulandari et al., 2012).

If Salmonella pullorum was resistant to antibiotics, it meant that the bacteria could grow continuously even though antibiotics had been given (Krisnaningsih et al., 2005). The resistance of Salmonella Pullorum to antibiotics occurs due to the unwise use of antibiotics in animals such as the use of antibiotics as feed additives in animal husbandry and for treatment and prevention. This resistance occured when there was a mutation in the bacterial DNA chromosome or there was specific new genetic material that could inhibit the mechanism of action of antibiotics so their effectiveness decreased or even disappeared to prevent or treat infections in livestock (Bari et al., 2008).

\section{Dilution method}

Minimum inhibitory concentration (MIC) results were presented in Fig 5 and 6 . Minimum Inhibitory Concentration (MIC) is the lowest concentration of sambiloto extract which was able to inhibit the growth of Salmonella pullorum. It appeared that the growth of bacteria at $10 \%$ concentration decreased compared to $5 \%$ concentration. The results showed that sambiloto extract $5 \%$ and $10 \%$ concentrations had color changes, while at concentrations of $20 \%$ and $40 \%$ there were no change in color the solution remained cloudy. The color change in the tube indicated the presence of acid production which then indicated the presence of bacterial growth while the tube that didn't show color change indicated no bacterial growth, this in accordance with the research of Holla et al., (2012). The incubation results of the positive control of Enrofloxacin were still clear, so they could not be compared with the treatment tubes. The results of the minimum inhibitory concentration (MIC) test could be observed in Table 4. Further tests were needed, which was the Minimum Bacteriocide Concentration (MBC) test by bacterial planting on Nutrient Agar media.

Based on Table 5, it showed that sambiloto extract at concentrations of $5 \%$ and $10 \%$ had positive values, meaning that there was growth of Salmonella pullorum. Sambiloto

Table 4: Minimum inhibitory concentration (MIC) on sambiloto extract and enrofloxacin.

\begin{tabular}{lcccccc}
\hline \multirow{2}{*}{ Plate number } & Concentration & \multicolumn{5}{c}{ Repetition } \\
\cline { 3 - 6 } & $5 \%$ & I & II & III & IV & V \\
\hline 1 & $10 \%$ & + & + & + & + & + \\
2 & $20 \%$ & + & + & + & + & + \\
3 & $40 \%$ & - & - & - & - & - \\
4 & Antibiotic control & - & - & - & - & - \\
5 & A & & & &
\end{tabular}

Description: (+) there is bacterial growth (-) no bacterial growth. extract at concentrations of $20 \%$ and $40 \%$ showed the same negative results as the control result of the antibiotic Enrofloxacin. Negative result meant that the administration of sambiloto extract effectively killed Salmonella pullorum

Table 5: Minimum bactericidal concentration (MBC) on sambiloto extract and enrofloxacin.

\begin{tabular}{|c|c|c|c|c|c|c|}
\hline \multirow{2}{*}{ Plate number } & \multirow{2}{*}{ Concentration } & \multicolumn{5}{|c|}{ Repetition } \\
\hline & & 1 & II & III & IV & V \\
\hline \multirow[t]{2}{*}{1} & $5 \%$ & + & + & + & + & + \\
\hline & & grow & grow & grow & grow & grow \\
\hline \multirow[t]{2}{*}{2} & $10 \%$ & + & + & + & + & + \\
\hline & & grow & grow & grow & grow & grow \\
\hline 3 & $20 \%$ & - & - & - & - & - \\
\hline 4 & $40 \%$ & - & - & - & - & - \\
\hline 5 & $\begin{array}{c}\text { Antibiotic control } \\
\text { (Enrofloxacin) }\end{array}$ & - & - & - & - & - \\
\hline
\end{tabular}

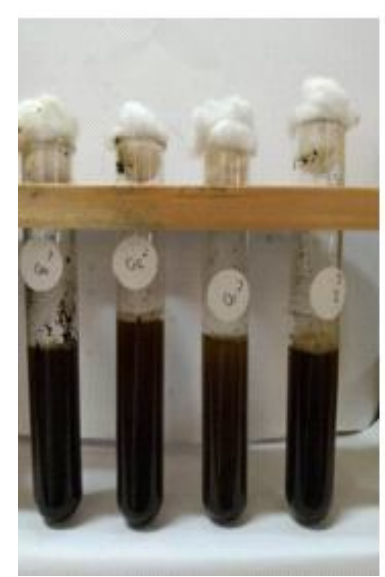

(a)

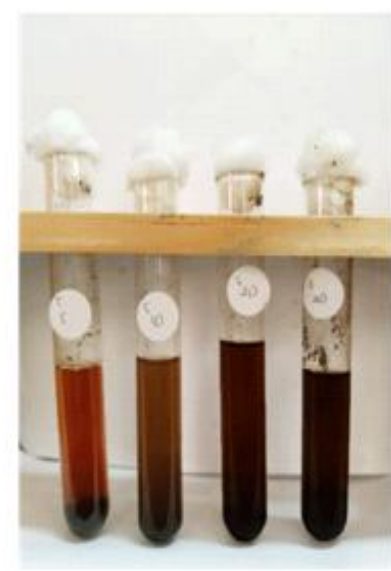

(b)
Fig 5: MIC test on sambiloto extract. a) before incubation, b) after incubation.

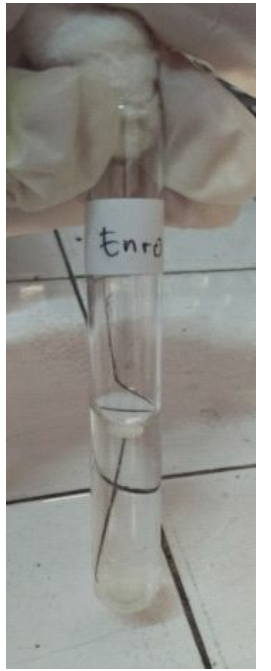

(a)

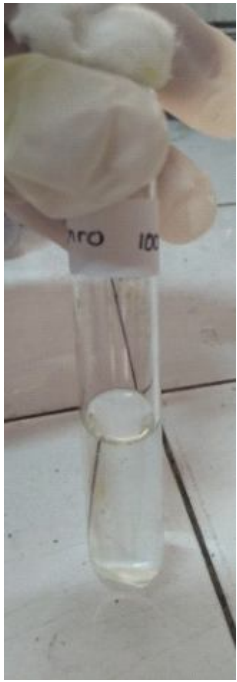

(b)
Fig 6: MIC test on the antibiotic Enrofloxacin a) before incubation, b) after incubation. 
Table 6: Probit test results to determine the value of lethal concentration $50\left(\mathrm{LC}_{50}\right)$.

\begin{tabular}{cccccccr}
\hline \multirow{2}{*}{ Probability } & \multicolumn{3}{c}{$95 \%$ confidence limits for concentration } & \multicolumn{3}{c}{ 95\% confidence limits for log (Concentration) } \\
\cline { 3 - 8 } & & Estimate & Lower bound & Upper bound & Estimate & Lower bound & Upper Bound \\
\hline Probit & .500 & 14.119 & 7.070 & 29.726 & 1.150 & .849 & 1.473 \\
\hline
\end{tabular}

at concentrations of $20 \%$ and $40 \%$, this can be proven in Fig 7. Minimum bactericidal concentration (MBC) value of sambiloto extract at $20 \%$ concentration because it was the lowest concentration that could kill Salmonella pullorum. The Minimum Inhibitory Concentration (MIC) value could be ascertained after the MBC test carried out was $10 \%$ concentration.

The results of the Minimum Bactericidal Concentration (MBC) test were then analyzed by probit using SPSS version 25.0 for windows, this was to determine the sensitivity of Salmonella pullorum ability toward sambiloto extract. The obtained Lethal Concentrration $50\left(\mathrm{LC}_{50}\right)$ of sambiloto extract was $14.119 \%$. Lethal concentrration $50\left(\mathrm{LC}_{50}\right)$ was concentration that could kill $50 \%$ the test bacteria population. The results of the probit test could be seen in Table 6 .

Sambiloto extract had antibacterial activity because it contained andrographolide, flavonoids, saponins, alkaloids and tannins. Based on several studies, sambiloto extract had an antimicrobial effect against Salmonella Pullorum. Damaged one of the constituent structures of bacterial cells could cause changes in the structure of bacteria and the work of bacteria (Cendranata et al., 2011).

Flavonoid compounds could inhibit bacterial growth by damaging the plasma membrane structure and causing changes in the permeability of bacterial cell walls at low concentrations (Puspawati et al., 2015). Flavonoid had mechanism of action by inhibiting cell membranes by forming extracellular and dissolved protein complex compounds so that they could damage bacterial cell membranes followed by the release of intracellular compounds (Nuria et al., 2009).

Alkaloid were one of the compounds contained in sambiloto extract which were alkaline and toxic to microbes, so they were effective in killing and inhibiting gram-negative bacteria and gram-positive bacteria. Alkaloid worked by disrupting the peptidoglycan constituent in bacterial cells so that the cell wall layer was not fully formed which causes the death of bacterial cells (Darsana et al., 2012). Alkaloid could inhibit nucleic acid synthesis and inhibit the energy metabolism of bacterial cells (Kusumo et al., 2017).

The content of other compounds was saponin, the mechanism of action of saponins was to reduce the surface tension of the bacterial cell wall so that the bacterial cell wall became lysed which could interfere with the survival of bacteria and eventually bacterial death occurred. Saponin could increase the permeability of bacterial cell membranes to change the structure and function of the membrane so that the cell membrane would be damaged and lysed (Maddox et al., 2010).

Other compound from sambiloto extract was tannin. Tannin was polyphenolic compound that could inhibit

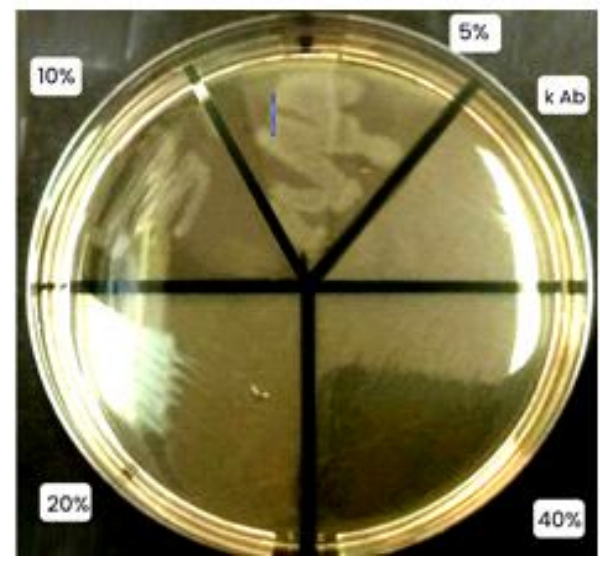

Fig 7: The results of the MBC test of sambiloto extract with concentrations of $5 \%, 10 \%, 20 \%, 40 \%$ and control of enrofloxacin.

bacterial cell adhesion, inhibit enzyme biosynthesis and interfered protein transport in the cell layer so that bacterial cells became lysed due to osmotic pressure and physical stress. The tannin compounds' mechanism of action was that they enter the cell wall of bacteria that had been lysed due to the action of saponin and flavonoid so tannin compound could easily enter the bacterial cell wall and coagulate the protoplasm of bacterial cells. These tannin compounds could inhibit and kill bacteria that react with bacterial cell membranes and destroy or inactivate the function of bacterial cell genetic material (Hidanah et al., 2018).

\section{CONCLUSION}

In conclusion, sambiloto extract has capability as antibacterial against Salmonella Pullorum 20\% concentration of sambiloto extract could inhibit and kill Salmonella Pullorum.

\section{Ethical approval}

The approval of this study was obtained from the Faculty of Veterinary Medicine, Surabaya, Indonesia (approval number: 2.KE.142.08.2018). This study conducted in the Bacteriology and Mycology Laboratory and Pharmacology Laboratory Faculty of Veterinary Medicine, Surabaya, Indonesia from September 2020 to August 2021.

\section{REFERENCES}

Akhsan, F., Harifuddin, Irwan, M. (2020). Cobb strain broiler chicken perfomance that given herbal turmeric. Tropical Animal Science. 2(2): 43-48. DOI: 10.36596/tas.v2i2.376. 
Alo, O.S., Ojo, O. (2007). Use of antibiotics in food animals: A case study of a major veterinary outlet in Ekiti-state, Nigeria. Nigerian Veterinary Journal. 28(1): 80-82.

Ansori, A.N.M., Susilo, R.J.K., Hayaza, S. (2021). Biological activity investigation of phytocomponents in mangosteen (Garcinia mangostana L.): In silico study. Indian Journal of Forensic Medicine and Toxicology. 15(1): 847-851. DOI: $10.37506 /$ ijfmt.v15i1.13522.

Bari, S.B., Mahajan, B.M., Surana, S.J. (2008). Resistance to antibiotic: A challenge in chemotherapy. Indian Journal of Pharmaceutical Education and Research. 24(1): 3-11.

Cendranata. (2011). Daya Hambat Ekstrak Daun Sambiloto (Andrographis paniculata) Terhadap Populasi Bakteri Pada Ulcer Recurrent Aphthous Stomatitis. Faculty of Dentistry, Airlangga University: Surabaya Vol. 60.

Chlebiez, A. and Sliżewska, K. (2018). Campylobacteriosis, salmonellosis, yersiniosis and listeriosis as zoonotic foodborne diseases: A review. Int. J. Environ. Res. Public Health. 15(5): 863. DOI: 10.3390/ijerph15050863.

Darsana, I.G.K., Besung, I.N.K. and Mahatmi, H. (2012). Potensi daun binahong [Anredera cordifolia (Tenore) Steenis] dalam Menghambat pertumbuhan bakteri Escherichia coli secara in vitro. Medicus Veterinus Indonesia. 1(3):337-351.

Fatiqin, A., Novita, R and Apriani, I. (2019). Pengujian Salmonella dengan Menggunakan Media SSA dan E. coli menggunakan Media Emba pada Bahan Pangan. Jurnal Indobiosains. 1(1): $22-29$.

Hidanah, S., Sabdoningrum, E.K., Wahjuni, R.S., Chusniati, S. (2018). Effects of meniran (Phyllanthus niruri L.) administration on leukocyte profile of broiler chickens infected with Mycoplasma gallisepticum. Veterinary World. 11(6): 834.

Hidanah, Sri, Sabdoningrum, E.K., Al Arif, M.A., Ansori, A.N.M., Hasanah, T.P, Widaya, L.V.A (2020). Sambiloto (Andrographis paniculata) extract improves the performance of animal model infected with Escherichia coli. Indian Journal of Forensic Medicine and Toxicology. 14(4): 3491-3496. DOI: $10.37506 /$ ijfmt.v14i4.12167.

Holla, G., Yeluri, R. and Munshi, A.R. (2012). Evaluation of minimum inhibitory and minimum bactericidal concentration of nano-silver base inorganic anti-microbial agent (Novaron $®$ ) against streptococcus mutans. Contemporary Clinical Dentistry. 3(3): 288-293.

Katzung, B. G. (2014). Basic and Clinical Pharmacology; Weitz, M., Boyle, P., Eds.

Kokate, C.K., Purohit, A.P. and Gokhale, S.B. (2001). Carbohydrate and derived products, drugs containing glycosides, drugs containingtannins, lipids and protein alkaloids. Text Book of Pharmacognosy, $7^{\text {th }}$ ed. India: Nitrali Prakashan.

Krisnaningsih, FMM, Widya, A, Wibowo, M.H. (2005). Uji Sensitivitas Isolat Escherichia coli Patogen Pada Ayam Terhadap Beberapa Jenis Antibiotika. Jurnal Sain Vet. 1(1): 13-18.

Kusumo, G.G. Fernanda, M.H.F. and Asroriyah, H. (2017). Identifikasi Senyawa Tanin Pada Daun Kemuning [Murraya panicullata (L.) Jack] Dengan Berbagai Jenis Pelarut Pengekstraksi. J. of Pharmacy and Science. 2(1): 29-32.

Laksmiani, N.P.L., Susanti, N.M.P., Widjaja, I.N.K., Rismayanti, A.A.M. and Wirasuta, I.A.G. (2015). Pengembangan Metode Refluks untuk Ekstraksi Andrografolid dari Herba Sambiloto (Andrographis paniculata Ness.). Jurnal Farmasi Udayana. 82-90.
Maddox, C.E., Laur, L.M. and Tian, L. (2010). Antibacterial activity of phenolic compounds against the phytopathogen Xylella fastidiosa. Curr Microbiol. 60(1): 53-8.

Mardiah. (2017). Uji Resistensi Staphylococcus aureusTerhadap Antibiotik, Amoxillin, Tetracyclin dan Propolis. Jurnal IImu Alam dan Lingkungan. 8(16): 1 - 6.

Mardiana, R.N. and N. Handayani. 2016. Uji Aktivitas Antibakteri Ekstrak Daun Sambiloto (Andrographis paniculata) terhadap Bacillus cereus dan Pseudomonas aeruginosa. Biofarmasi. 14(1): 19-24.

Miller, K.L., Liebowitz, R.S. and Newby, L.K. (2004). Complementary and alternative medicine in cardiovascular disease: A review of biologically based approaches. Am. Heart. J. 147: 401-411.

Miranda, C.D. and Zemelman, R. (2002). Bacterial resistance to oxytetracycline in Chilean salmon farming. Aquaculture. 212(1-4): 31-47.

Narayanan, K.R., Dhasarathan, P., Manujula, M. and Thenmozhi, M., (2021). Immunomodulatory efficiency of Abelmoschus esculentus in Swiss Albino Mice. Indian Journal of Animal Research. 55(4): 401-406. DOI: 10.18805/ijar.B-3966.

Nasution, F.M., Chalil, M.J.A., Annisa. and Lubis, M. (2019). Efektifitas Ekstrak Daun Sambiloto (Andrographis Paniculata Ness) dengan Kloramfenikol terhadap Pertumbuhan Bakteri Salmonella Typhi Secara in vitro. Jurnal IImiah Simantek. 3(3): 1.

Novitasari, P.R., Astuti, N.T, Tjandrawinata, Pramono, S. and Nugroho, A.E. (2020). A Simple Liquid-Liquid Fractionation (LLF) Method for Isolating Deoxyandrographolide dan Andrographolide from Herbs of Andrographis paniculata (Burm, F) Ness and Its Cytotoxic Activity on 3T3-L1 Preadipocyte Cells. J. Food Pharm. Sci. 8(3): 306-314.

Nuria, M.C, Faizaitun, A. and Sumantri. (2009). Uji Aktivitas Antibakteri Ekstrak Etanol Daun Jarak Pagar (Jatropha curcas L) Terhadap Bakteri Staphylococcus Aureus Atcc 25923, Escherichia Coli Atcc 25922, Dan Salmonella Typhi Atcc 1408. Mediagro. 5(2): 26-37.

Ousaaid, D., Mansouri, I., Laaroussi, H., ElGhouizi, A., Lyoussi, B., ElArabi, I. (2020). Phytochemical Content and Antioxidant Activity of Flesh Fruits Rosa canina Extracts Collected from Ait Ayach Midelt, Indian Journal of Agricultural Research. 54(3): 373-377.DOI: 10.18805/ IJARe.A-494

Owuama, C.I. (2017). Determination of minimum inhibitory concentration (MIC) and minimum bactericidal concentration (MBC) using a novel dilution tube method. African Journal of Microbiology Research. 11(23): 977-980.

Puspawati, N.M. Sari, P.P. and Rita, W.S. (2015). Identifikasi dan Uji Aktivitas Senyawa Tanin dari Ekstrak Daun Trembesi [Samanea saman (Jacq.) Merr] Sebagai Antibakteri Escherichia coli (E. coli). J. Kimia. 9(1): 27-34.

Rani, J., Kapoor, M. and Kau, R. (2017). In-vitro anti-bacterial activity and phytochemical screening of crude extracts of Catharanthus roseus L. (G.) Don. Agric. Sci. Digest. 7(2): 106-111. DOI: 10.18805/asd.v37i2.7983.

Sabdoningrum, E.K., Hidanah, S., Ansori, A.N.M., Fadholly, A. (2020). Immunomodulatory and antioxidant activities of Phyllanthus niruri L. extract against the laying hens infected by Escherichia coli. Research Journal of Pharmacy and Technology. 13(5): 2246-2250. DOI: 10.5958/0974-360X.2020.00404.7 
Sànchez-Salazar, E., Gudiño, M.E, Sevillano, G., Zurita, J., GuerreroLòpez, R., Jaramillo, K. and Calero-Cáceres, W. (2019). Antibiotic resistance of Salmonella strains from layer poultry farms in central Ecuador. Journal of Applied Microbiology. (128): 1347-1354. DOI:10.1111/jam.14562

Savin, M., Alexander, J., Bierbaum, G., Hammerl, J.A., Hembach, N., Scwartz, T., Schmithausen, R.M., Sib, E., Voigt, A. and Kreyenschmidt, J. (2021). Antibiotic resistant bacteria, antibiotic resistance genes and antibiotic residues in wastewater from a poultry slaughterhouse after conventional and advanced treatments. Nature Scientific Report. 11(1): 16622. DOI: 10.1038/s41598-021-96169-y.
Suwarta, F.X., Suryani, C.L. and Amien, L. (2021). Supplementation of turmeric and Andrographis paniculata powder in ration on performance of laying hen. JPI. 23(2): 151-158. DOI: 10.25077/jpi.23.2.151-158.2021.

Wahyuni, D.K., Ansori, A.N.M., Vidiyanti, F. (2017). GC-MS analysis of phytocomponents in methanolic extracts of leaf-derived callus of Justicia gendarussa Burm. f. Bioscience Research. 14(3): 668-677.

Wulandari, L., Ardana, I.B.K. and Suada, I.K. (2012). Pemberian Tylosin dan Gentamisin Menurunkan Angka Lempeng Total Bakteri Daging Broiler Betina. Indonesia Medicus Veterinus. 1(2): 252-267. 